\title{
Design and implementation of an alternative process for the manufacture of bricks from gold mine tailings
}

\author{
Diseño e implementación de un proceso alternativo para \\ la fabricación de ladrillos a partir de relaves mineros de Oro \\ Juan Valdez Loaiza ${ }^{1 *} \quad$ José Aguilar Franco $^{1} \quad$ Lourdes Sánchez Vargas $^{1}$ \\ Giovani Alatrista Góngora ${ }^{1} \quad$ Alexia Pardo Figueroa Dianderas ${ }^{1}$ \\ Recibido 10 de noviembre de 2017, aceptado 23 de diciembre de 2018 \\ Received: November 10, 2017 Accepted: December 23, 2018
}

\begin{abstract}
In Arequipa - Peru, tailings produced from the gold cyanidation process are deposited in tailings dumps. This accumulation creates the need for large spaces, high maintenance costs, and a negative impact on the environment. The present study aims to develop a process for reusing gold mine tailings as a raw material for the manufacture of bricks. This study deals with important aspects of the mining industry involved in sustainable development, namely the transformation of an environmental liability into an environmental asset. This work will seek to address two problems related to environmental damage: the buildup of toxic solid wastes at mining sites, and the over-exploitation of natural resources in the brick production process.

The proposed process has been divided into three stages: (I) thickening and molding; (II) filtering, mixing and neutralizing; and (III) drying and sintering. The development and validation of the process and the evaluation of the final featured products allow defining the process as "recycling" (collection, processing, trading, and use of materials considered wastes).

Standard procedures in brick manufacture analyzed physical and mechanical quality from bricks produced. Results showed that the bricks comply with current regulations for materials in compression resistance, maximum absorption, and dimensional variation tests. It is concluded that the enormous environmental liability represented by mining tailings can be used as a raw material within the construction materials industry.
\end{abstract}

Keywords: Gold cyanidation, environment, sustainable.

\section{RESUMEN}

El objetivo de este trabajo fue desarrollar un proceso para el aprovechamiento de los relaves generados por el proceso de cianuración para la recuperación de oro, utilizándolos como materia prima para la obtención de ladrillos de construcción; atendiendo aspectos de sumo interés para la industria minera como el desarrollo sostenible, la transformación de un pasivo en activo ambiental, encarando simultáneamente dos problemas relacionados con el daño al medio ambiente: la utilización de material catalogado como desecho (relave minero) y la sobre explotación de recursos naturales como las arcillas para la fabricación de ladrillos.

\footnotetext{
1 Instituto de Energía y Medio Ambiente. Universidad Católica San Pablo. Calle Sucre 601, CEP 691. Arequipa, Perú. E-mail: jcvaldez@ucsp.edu.pe; jaaguilar@ucsp.edu.pe; lourdes.sanchez.vargas@ucsp.edu.pe; gralatrista@ucsp.edu.pe; apardofigueroa@ucsp.edu.pe

* Corresponding Author: jcvaldez@ucsp.edu.pe
} 
El proceso propuesto para la producción de ladrillos ha sido dividido en tres etapas: Espesado y neutralizado (I), Filtrado, mezclado y moldeado (II), Secado y sinterizado (3); considerando dentro de los parámetros de fabricación la presencia de grava y ceniza volcánica como aditivos. El desarrollo y validación del proceso, y la evaluación de las características del producto final, permiten definir el proceso como "reciclaje" (colecta, procesamiento, comercialización y uso de materiales considerados como desechos).

Una vez implementado el proceso, se analizaron de las características físicas y mecánicas de los ladrillos obtenidos. Los resultados muestran que, previamente neutralizado el primer agente contaminante (cianuro), se obtiene un producto que cumple con la normatividad vigente de albañilería para los ensayos de resistencia a la compresión, absorción máxima y variación dimensional. Se concluye que el enorme pasivo ambiental que representan los relaves mineros, puede servir como materia prima para la industria de materiales de construcción.

Palabras clave: Cianuración de oro, medio ambiente, sostenible.

\section{INTRODUCTION}

The mining industry has had a long history of negative environmental impacts. Previously, criterias and technologies have been put into effect that produce maximum energy efficiency; both in the manufacture and development of materials. In the mining industry; most of the environmental research related to solid wastes, seek to improve management, conditioning, storage and potential waste enrichment operations. In 1995, the WBCSD (World Business Council for Sustainable Development) was created in Switzerland, defining and summarizing a series of objectives [1] in:

- Implemention of Eco-efficient and Corporate Social Responsibility (CSR) as a fundamental principle for all companies; encouraging communication and dialogue between entrepreneurs, the State, NGOs, the academic community and society in general.

- Participation in the definition of policies that will allow sustainable development. Keeping together with organizations, strict exchanges of information on best practices in sustainable development.

Our research was done considering experimentation first at laboratory level, from which design parameters of interest were obtained; then, manufacture was replicated at industrial level.

Recently, the construction sector in Perú has an approximate increase of 5\% (INEI, 2015). This is one of the most attractive sectors due to the high demand that represents almost 400 thousand housing units nationwide (Fondo Mi Vivienda FMV, 2016). The brick manufacture sector has had a leading role in the expansion of this industry. Generally, bricks are made from non-renewable resources (such as clays) and are handcrafted with low production costs [2]. In Peru, around $27 \%$ of the market is unregulated and informal [3] This informality leaves a dearth of knowledge in the manufacturing processes such as: over-explotation of clay mines, inefficient brick mixtures, and the emission of greenhouse gases due to wood-fueld drying ovens [2]. These issues have led researchers to look for alternatives to clay mining [4-5].

Mine tailings are deposited in dumps as established by Peruvian regulations. Those also mention tailing disposal practices, such as: underground landfill, thickened discharge method, and de-watered tailings disposal. However, the regulations do not consider the use of mine tailings as a resource. The transformation of the tailings raw materials for products to be used in engineering unites the mining sector with civil construction. This unification incorporates new markets to the mining industry; reducing pollution, optimizing the use of exploited resources, and creating new sources of employment [6].

The use of mine tailings for civil construction has been going on for more than 60 years [6].Russia's joint-stock Company has been using its tailings for various applications, including the manufacture of ceramics and bricks, acheiving a mass recovery of the order of $40 \%$. 
In studies by Mount Wright-Québec, Canada (MWQ), [6] mortars were obtained from a mixture of cement and tailings were used to seal an underground drainage canal. After a series of tests with 33 different mixtures of cement and tailings (all characterized in terms of compressive strength, ease of flow, liquid retention capacity, contraction, expansion and density), the optimal mass ratio of cement, water, and mine tailings used in the mortar was $1.0: 1.9: 2.5$, respectively. As a result, from $504 \mathrm{~m}^{3}$ of filled channel, $65 \%$ was filled with the mixture with mine tailings, having considerable reduction of operative costs because of the reduction of cement needed.

[6] Other studies evaluated alternatives for largescale use of iron mine tailings in Brazil, the second largest iron producer in the world. As a result, it was verified that enormous environmental liability can serve as raw material for use in engineering, as long as they comply with the standards proposed in this case by the Brazilian Association of Technical Standards.

[7] Describes the environmental problems of mining tailings in Peru. They evaluated the reuse of mining tailings as inputs in the production of construction aggregates for the manufacture of bricks and tiles, the tailing evaluated in this case is of sulphurated polymetallic nature. The conclusion of this research states that the final product obtained from polymetallic tailings is not polluting.

In the publication of [8], the following conclusions are worthy of note:

- Recycling wastes as useful materials is a very important environmental management tool to achieve sustainability.

- Research and development of new materials or components for civil construction from tailings as raw material, is a complex and multidisciplinary task (environmental, technical, financial, legal, market and social).

\section{METHODOLOGY}

\section{Laboratory assay methods}

Manufacture of bricks from gold mine tailings involves conventional methods; however, the raw material from tailings were pre-conditioned in order to ensure no toxicity. Characterization and conditioning tests (sedimentation, neutralization, chemical and mineralogical components) were carried out in laboratory. As a result, the considerations for the elaboration of test specimens (laboratory models) and its subsequent replication at prototype level (industry model) took as comparative reference the Peruvian Technical Norms for manufacture of bricks. Laboratory assays followed the procedure described by Romero \& Flores (2010) and recommendations of specialists in the área.

\section{Characterization and assays}

The mine tailings to be transported and processed, require conditioning by hydration, obtaining a solid ratio of: 2.5: 1 . This hydration is only maintained for transportation stage by pumping. Once in the system, it is necessary to extract the excess of water to be able to carry out the processes of brick manufacture.

Sedimentation tests of hydrated tailings were performed at laboratory. We experimented with different doses of the flocculant Magnafloc with mixture at $250 \mathrm{rpm}$. After the homogenization, the sedimentation process was determined using a 1000 $\mathrm{ml}$ measuring cylinder, taking record with intervals of 15 seconds until greater change in the height of the mud column was not observed. Subsequently, the dose and sedimentation time were determined. After the increasing of density by sedimentation, the criteria for neutralization of cyanide was established with mineralogical and chemical analyses (metals and cyanide), as well as pulp density and specific gravity of the solids. Based on these characterizations, neutralization tests were performed using two chemical complexes $\left(\mathrm{H}_{2} \mathrm{SO}_{4} / \mathrm{CN}\right.$ and $\left.\mathrm{H}_{2} \mathrm{SO}_{4}: \mathrm{H}_{2} \mathrm{O}_{2}\right)$; by which the appropriate dose was established for the maximum removal of cyanide.

\section{Test Cylinder assays}

Manufacture of test pieces was carried out in six stages (Parameters in Table 1): Selection of raw material, mixing, molding, drying, cooking and cooling. $30 \mathrm{~kg}$ of mine tailings were used as sample for granulometric, geochemical and mineralogical characterization.

\section{Plant Brick manufacture procedures}

The proposed prototype (based on the results obtained in the laboratory) has 3 units as shown in the scheme of Figure 1: Thickened and neutralized 
Table 1. Parameters for manufacture of test cylinders.

\begin{tabular}{|l|c|}
\hline \multicolumn{1}{|c|}{ Parameters } & Value \\
\hline Mixing time* & $10-15 \mathrm{~min}$ \\
\hline Weight of test cylinder & $200 \mathrm{~g}$ \\
\hline Moisture & $25 \%$ \\
\hline Drying time & $24 \mathrm{~h}$ \\
\hline Oven dry at $200^{\circ} \mathrm{C}$ & $60 \mathrm{~min}$ \\
\hline Elimination of gas a $400^{\circ} \mathrm{C}$ & $120 \mathrm{~min}$ \\
\hline Baking $950^{\circ} \mathrm{C}$ & $180 \mathrm{~min}$ \\
\hline Slow cooling & $180 \mathrm{~min}$ \\
\hline
\end{tabular}

* In the mixing stage of mine tailings, volcanic ashes and pozzolana (additives included in the mixture used to determine if they added a greater resistance to the brick), 8 specimens of $200 \mathrm{~g}$ were produced (Table 2). The drying process was divided into two stages, first at room temperature for one day; then drying in a muffle oven at $200{ }^{\circ} \mathrm{C}$ for one hour; baking at $950{ }^{\circ} \mathrm{C}$ for 3 hours; and finally the bricks were allowed to cool to $20^{\circ} \mathrm{C}$ for 3 hours and the compressive strength tests were carried out (Table 2). (unit 1) where solids and liquids are separated from the mine tailings for subsequent neutralization. Filter, Mixing and Molding (unit 2), where additives are added for the resistance to the compressive strength and for shape proccess to the final product. Finally, Drying and Sintering (unit 3) for final product baking. Figure 2. shows prototype built and in operation.

Unit 1: In order to sediment and reduce their percentage of liquids, the mine tailings are sucked directly from the cyanidation process to the Lamella Thickener. Here starts the separation of solids and liquids. The solid part is directed to the neutralizer, which reduces the amount of cyanide in the tailings. The liquid part is recirculated to the leach plant (it is reused again in the cyanidation process because of its high cyanide content).

The mine tailings enter this component through a piping system. Two complementary accessories were

Table 2. Cylinder test composition.

\begin{tabular}{|c|c|c|c|c|}
\hline Sample & Gold mine tailing (\%) & Clay (\%) & Ashes (\%) & Compressive strength test $\mathbf{( K g / \mathbf { c m } ^ { 2 } )}$ \\
\hline Prob 1 & 90 & 10 & 0 & 6.42 \\
\hline Prob 2 & 90 & 5 & 5 & 6.36 \\
\hline Prob 3 & 85 & 12 & 3 & 23.07 \\
\hline Prob 4 & 87 & 10 & 3 & 12.17 \\
\hline Prob 5 & 85 & 10 & 5 & 10.54 \\
\hline Prob 6 & 85 & 10 & 5 & 9.86 \\
\hline Prob 7 & 82 & 15 & 3 & 23.86 \\
\hline Prob 8 & 80 & 15 & 5 & 25.45 \\
\hline
\end{tabular}

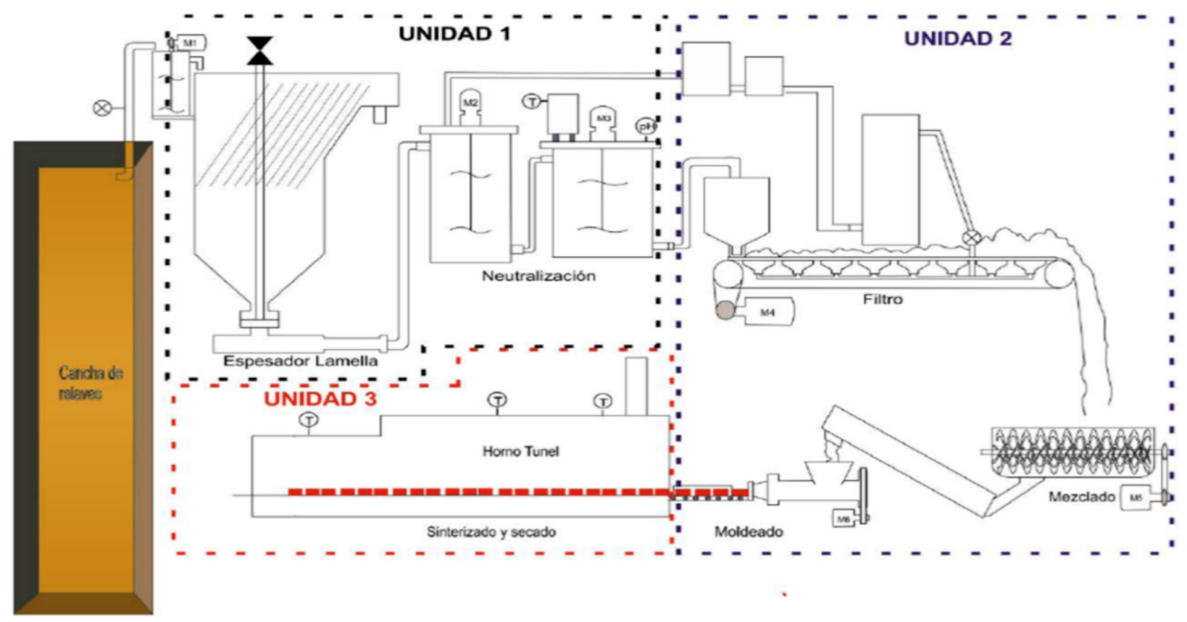

Figure 1. Scheme of experimental plant. 


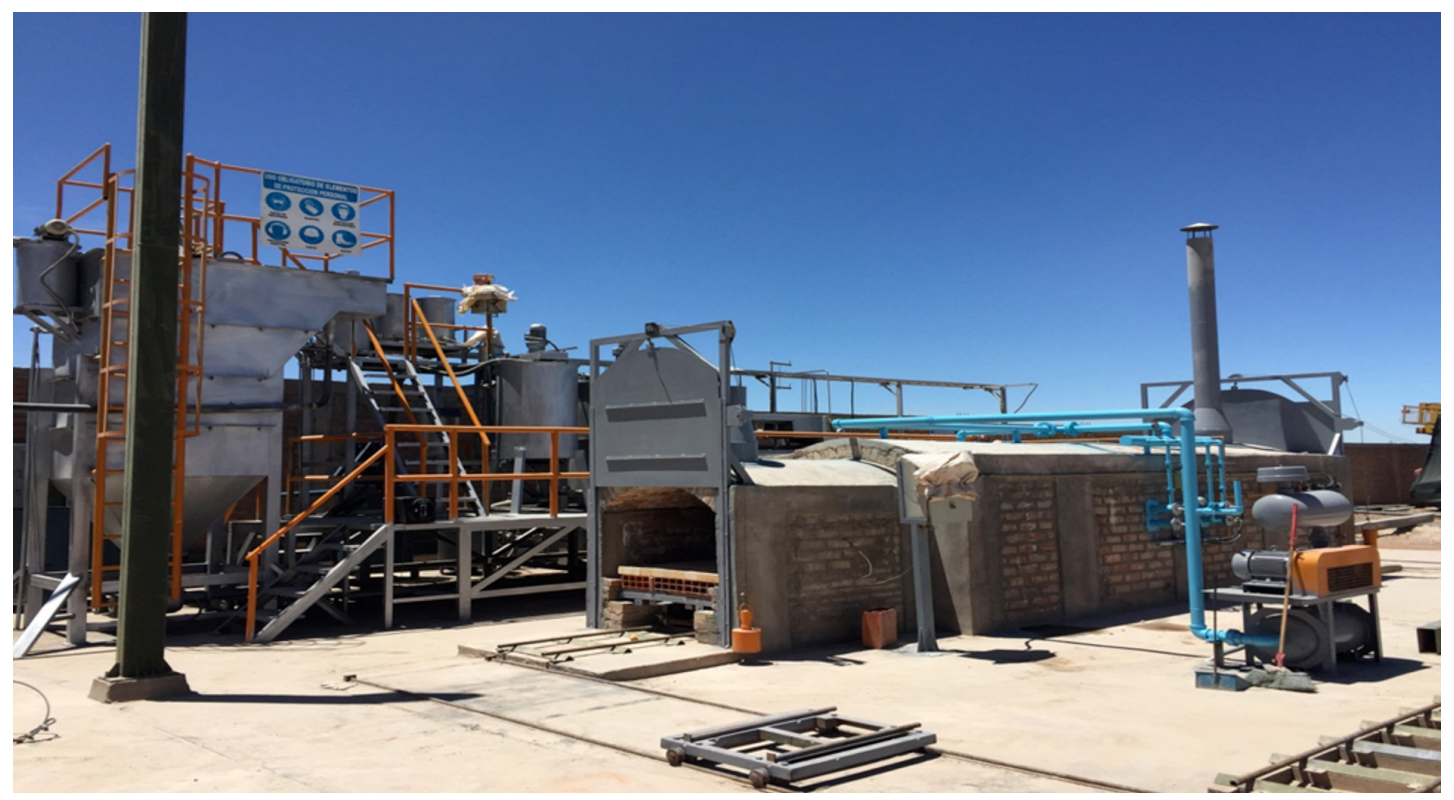

Figure 2. Prototype for bricks manufacture.

designed and built for this component: a feeder tank and a push system. The first one mix tailings coming from the field by using the Magnafloc flocculant and takes them to the Lamella Thickener. The pump system moves the solid part of the tailings mixture to the conditioning tank, which conditions the sedimented tailings, achieving a concentration of solid of around $30 \%$. The product then moves in the neutralizing tank, where the cyanide is neutralized through the addition of Caro's acid, until it meets the environmental quality standards of $0.1 \mathrm{mg} / \mathrm{L}$ in the liquid part of the tailings mixture.

Unit 2: It is composed by a strip filter and a helical feeder. The first helps filtering the neutralized tailings, allowing separation of the mixture in neutralized solids and cyanide-free liquids. Then, solid part is directed to the mixer in order to form a neutralized mine tailing mixture with clay, and The liquid part is absorbed by suction trays to be recirculated to provide greater resistance to the brick, The filtered solids are mixed with clay in the mixer.

The tailings enter the extruder, where the moisture is maintained at $28 \%$ (because with higher values it may stick to the equipment). The mixture leaves the extruder with the chosen geometry and then, passes to the cutter to obtain the bricks. The bricks dry under room temperature for 7 days, which helps reducing most of its moisture content and then, pass to the drying process in the oven

Unit 3: The firing and sintering of the bricks starts using a furnace at an average temperature of $1000^{\circ} \mathrm{C}$. This process is divided in three stages:

- Pre-heating: In the first three meters of the oven, the required temperature is $200{ }^{\circ} \mathrm{C}$ to $400{ }^{\circ} \mathrm{C}$.

- Firing: From the third to the fifth meter, with an average temperature of $1000^{\circ} \mathrm{C}$. The LPG burners will be installed in this area, where a pyrometer measures the temperature.

- Cooling: From the fifth to the eighth meter, here the temperature drops from $400{ }^{\circ} \mathrm{C}$ to $200{ }^{\circ} \mathrm{C}$.

\section{MATERIALS}

The equipment used for testing, at laboratory and plant, was:

- Pyrometer - Thermocouple: measures the temperature in the heat injection stage in Unit 3.

- Mini PH controller: measures the level of acidity present in the neutralizing tank of Unit 1.

- Cyanide Meter: measures the cyanide level of Unit 1.

- Manometer: measures the gas pressure in the furnace of Unit 3.

- A muffle oven was used in the laboratory tests for drying and cooking of bricks. 


\section{RESULTS}

\section{Tailings sedimentation time}

It was determined that a dose of $1.00 \mathrm{~g}$ of Magnafloc/ $\mathrm{Kg}$ of mine tailings allows a greater sedimentation of mud at a higher speed $(0.154 \mathrm{~cm} / \mathrm{s})$, compared to the other doses used $(0.119 \mathrm{~cm} / \mathrm{s}$ and $0.148 \mathrm{~cm} / \mathrm{s})$. Also, the degree of final compaction in the graduated test cylinders, indicates that doses of 0.75 and $1.00 \mathrm{~g} /$ $\mathrm{kg}$ of Magnafloc give the best results (about $12 \mathrm{~cm}$ of supernatant) after 2 minutes of rest.

\section{Granulometry}

It was determined that gold mine tailings and clay are 50\% above of 150 microns, indicating that they possess extremely fine materials that would provide good plasticity for brick's elaboration.

\section{Mineralogical analysis of raw material}

Table 3 shows that mineralogical association between tailings and silicon is above $80 \%$, indicating its high degree of applicability for construction materials. In the same way, the presence of hydrated silicates such as muscovite $(6 \%)$, and quartz ( $86 \%)$, because of their high content of silicon, allow the encapsulation of heavy metals, reducing the toxicity.

\section{Gold mine tailing neutralization}

It was determined that with a neutralization radius of $\mathrm{H}_{2} \mathrm{SO}_{5} / \mathrm{CN}$ - of 2.0-3.0, and a reaction time of one minute, $99 \%$ efficiency was achieved in neutralization process. This helped reducing the total cyanide content from $281.43 \mathrm{mg} / \mathrm{L}$ of Total CN to $0.01 \mathrm{mg} / \mathrm{L}$ (Analysis performed by AGQ PERU S.A.C. laboratories). Table 4 shows the cyanide concentration $(\mathrm{mg} / \mathrm{L})$ before and after neutralization by the established dose of $\mathrm{H} 2 \mathrm{SO} / \mathrm{CN}$ - of 3/L.

\section{Cylinder Test}

Compressive strength results indicate that the ashes as part of the mixture, exerts an adverse effect on the resistance as its concentration increases. The test cylinders made with a higher content of tailings; "Prob 3", "Prob7" and "Prob 8", showed higher resistance to compression with $23.07,23.86$ and $25.45 \mathrm{Kg} / \mathrm{cm}^{2}$ respectively. This may be the result of their lower ash and higher clay content. On the other side, "Prob 1" and "Prob 2" showed lower compressive strength, having values of 6.36 and $6.42 \mathrm{Kg} / \mathrm{cm}^{2}$ respectively (they contain a higher percentage of ash).

\section{Brick tests}

Table 5 shows the results of absorption, compressive strength and dimensional variation tests applied to the bricks from the prototype plant. According to the E-070 masonry regulations, it is determined that quality reference levels were accomplished $(<22 \%$ of absorption; 17.6 MPa of compressive strength; type $\mathrm{V}$ and IV bricks of high strength and durability, suitable for diverse constructions needs).

\section{Toxicity}

A comparative analysis (Table 6) with permissible limits of EPA-FCR 261.24 showed that in the four

Table 3. Mineralogical Analysis by X-Ray Diffraction.

\begin{tabular}{|l|l|c|}
\hline \multicolumn{1}{|c|}{ Mineral name } & \multicolumn{1}{c|}{ General formula } & Approx. result (\%) \\
\hline Quartz & $\mathrm{SiO}_{2}$ & 86 \\
\hline Mica (Muscovite) & $\mathrm{KAI} 2\left(\mathrm{Si}{ }_{3} \mathrm{Al}\right) \mathrm{O} 10(\mathrm{OH}, \mathrm{F}) 2$ & 6 \\
\hline Plagioclase $($ Andesine $)$ & $(\mathrm{Ca}, \mathrm{Na})(\mathrm{Al}, \mathrm{Si}) 4 \mathrm{O} 8$ & 3 \\
\hline Hematite & $\mathrm{Fe}_{2} \mathrm{O}_{3}$ & $<$ L.D \\
\hline Siderite & $\mathrm{FeCO}_{3}$ & $<$ L.D \\
\hline Chalcopyrite & $\mathrm{CuFeS}_{2}$ & $<$ L.D \\
\hline
\end{tabular}

Table 4. Cyanide content in tailings samples.

\begin{tabular}{|c|c|c|c|c|c|}
\hline Sample \# & $\begin{array}{c}\text { Sample } \\
\text { Name }\end{array}$ & $\begin{array}{c}\text { Sample } \\
\text { description }\end{array}$ & $\begin{array}{c}\text { Sample } \\
\text { provenance }\end{array}$ & $\begin{array}{c}\text { S/Neutralization } \\
\mathbf{C N}(\mathbf{m g} / \mathbf{L})\end{array}$ & $\begin{array}{c}\text { C/Neutralization } \\
\mathbf{C N}(\mathbf{m g} / \mathbf{L})\end{array}$ \\
\hline SS13000805 & Tailing 1 & $\begin{array}{l}\text { No neutralized } \\
\text { Sample }\end{array}$ & $\begin{array}{l}\text { CEPROMET Minera } \\
\text { Porvenir S.A.C }\end{array}$ & 281,43 & $<0.01$ \\
\hline
\end{tabular}


Table 5. Brick tests.

\begin{tabular}{|l|c|c|}
\hline \multicolumn{1}{|c|}{ Feature } & Unit & Result \\
\hline Dry weight & $(\mathrm{g})$ & 3119.76 \\
\hline $\begin{array}{l}\text { Average Weight Sat. Sup. Seco } \\
(24 \mathrm{~h})\end{array}$ & $(\mathrm{g})$ & 3686.8 \\
\hline Absorption & $(\%)$ & 18.18 \\
\hline Gross Area & $\left(\mathrm{cm}^{2}\right)$ & 147.946 \\
\hline Load & $(\mathrm{Kg})$ & 32704.4 \\
\hline Breaking strength & $(\mathrm{MPa})$ & 21.712 \\
\hline
\end{tabular}

analyzed elements, according to TCLP 7058, there is no toxicity in the brick produced by the prototype plant.

\section{DISCUSSION}

Mineralogical results show same tendencies as in previous studies where it is shown that mineralogical and chemical composition of gold mine tailings are similar to conventional material composition used for construction of bricks [9]. Among the main components found, the presence of oxides, muscovite (6\%) and quartz (86\%), are highlighted. However, characteristics of mine tailings depend on the geographic location and type of gold ore extraction process,[10] verified that gold mine tailings characteristics vary according to the place of origin extraction, and even within the same area of the dump [11], in this Project, we found high concentrations of oxides: $\mathrm{SiO}_{2}$ : 38.60; $\mathrm{Al}_{2} \mathrm{O}: 7.06 ; \mathrm{Fe}_{2} \mathrm{O}_{3}: 1276$; $\mathrm{CaO}: 29.24$. Although oxides predominate; it was established that silicates are the main contributors of better mechanical characteristics for the use of materials destined for construction.

In general, it should be noted that content of sulphide minerals in a dump is $40 \%$; On the contrary, lower layers indicate the content of goethite, quartz, chlorite, muscovite, calcite, hematite, pyrrhotite and high concentrations of heavy metals such as arsenic, copper and lead, depending on the mineral extraction base [9]. It is important to perform a characterization in vertical profiles of mine dumps in order to estimate the amount of oxidized minerals available. The analyzed tailings have fine components suitable to provide plasticity to the brick; results show that $80 \%$ of tailings particles are close to 150 $\mu \mathrm{m}$ of size, having consistence with results of (20), where tailings particles were around $80 \%$ of dough per $200 \mu \mathrm{m}$ sieve and $12 \%$ of dough of $90 \mu \mathrm{m}$.

The dose that allowed the highest neutralization (99\%) was $3 \mathrm{~g}$ of $\mathrm{H} 2 \mathrm{SO} 5$ per gram of cyanide; these values are close to that found by [8], who states that the appropriate dosage could be 5 to $15 \mathrm{~g}$ of $\mathrm{H} 2 \mathrm{SO} 5$ per $\mathrm{g}$ of cyanide. However, it is to take silt content into account, since it may decrease the effectiveness of $\mathrm{H} 2 \mathrm{SO}$, requiring larger doses. According to TCLP procedures, it is established that cyanide in a waste to be considered dangerous must be above $3.5 \mathrm{mg} / \mathrm{L}$. Total cyanide, should be greater than $14 \mathrm{mg} / \mathrm{L}$ to be considered dangerous [12], which is confirmed by [13], who found dermal effects by 15 ppm hydrogen cyanide. In the present study, results after neutralization were close to $0.01 \mathrm{mg} / \mathrm{L}$ of total cyanide. This evidence suggests that gold mine tailings, if processed correctly, could provide a benefit to the brick manufactuing industry.

The results on cylinder samples with different complements determine that the gold mine tailings mixed with clay allowed to obtain resistance to compression up to $25.5 \mathrm{~kg} / \mathrm{cm}^{2}$; approaching the results by [5], where it was established that the use of gold mine tailings has high potential for application in the industry of materials; However, in this study, in order to obtain a material of higher hardness, some additives must be applied as cement, obtaining compressive strengths of up to $36 \mathrm{~kg} / \mathrm{cm}^{2}$.

The average compressive strength of the refractory bricks produced by the prototype plant was 21,712 $\mathrm{MPa}$, This value contrasts with other results where only values close to $18 \mathrm{MPa}$ were found [5]. These

Table 6. Results of Brick Toxicity Analysis.

\begin{tabular}{|l|c|c|c|c|c|}
\hline \multirow{2}{*}{ Sample description } & \multirow{2}{*}{ Sample Provenance } & \multicolumn{4}{|c|}{ TCLP *7058 } \\
\cline { 3 - 6 } & & $\mathbf{C d}(\mathbf{m g} / \mathbf{L})$ & $\mathbf{C r}(\mathbf{m g} / \mathbf{L})$ & $\mathbf{H g}(\mathbf{m g} / \mathbf{L})$ & $\mathbf{P b}(\mathbf{m g} / \mathbf{L})$ \\
\hline Brick: Final Product & Minera Porvenir S.A.C & 0.149 & 0.0026 & $<0.012$ & 0.855 \\
\hline (EPA - FCR 261.24) & & 1.0 & 5.0 & 0.2 & 5.0 \\
\hline
\end{tabular}


values also contrast with those indicated by [14], who established the adverse effect of mine tailings in compression strength and other characteristics; this due to the fine nature of tailings; however, Our results show that are mineralogical characteristics from gold mine tailings allow to enhance mechanical and physical characteristics, complying with technical quality standards, which coincides with other studies such as [15].

[16] developed tests and analysis of parameters related to the mechanical behavior of an ecological brick produced with mining waste, using compression and resistance tests. They observed that the results obtained in the production were satisfactory, showed a mechanical resistance of 4.9 times higher, when it's compared with an conventional bricks, reaching maximum values of $33.5 \mathrm{MPa}$. In the present work, we obtained a brick with an average resistance of 21.7 MPa. However, [17] results produced in an ecological brick plant (soil-cement type) showed an compresion strength of $2.3 \mathrm{MPa}$, In that sense [18] consider that the minimun resistance acceptable for constructive elements must not be less than 1.5 MPa. With which our results are highly encouraging. The results proposed are within the standardized parameters of different international standards such as ABNT NBR 15270-1 (Brazil), NTC 4205 (Colombia) and NTP standards 331.0171978 and E.070 (Perú).

The levels of cyanide obtained after treatment are 99\% lower than those present in the original slurry ( $<1 \mathrm{mg} / \mathrm{L}$ ), that comply with international technical standards presented in the results comparison [19]. Other methods such as the "coal in leaching" presented by [20] shows a decrease of up to $93 \%$ in the amount of cyanide in concentrations of $1000 \mathrm{mg} / \mathrm{L}$.

For an adult person. The average lethal dose of cyanide ingestion is about of 1 to $4 \mathrm{mg} / \mathrm{kg}$. In respiratory exposures, the concentrations can vary from 100 to $300 \mathrm{mg} / \mathrm{L}$ [21]. Therefore, as the posttreatment analysis shows, the material used for the bricks does't have health risks and it can be used in housing constructions as well as other industrial or pavement constructions.

In adition, these mineralogical characteristics could be related to the chemical characteristics non-toxic to the human being, as detailed in the results by TCLP, using as reference values of toxicity to the established by EPA - FCR 261.24.

\section{CONCLUSIONS}

Cyanide tailings present adequate characteristics as a raw material for manufacture of high strength building materials. It is established that high content of silicates is favorable for manufacture of materials. Finally due to its high contents of cyanide, it is necessary to pre-pretreat through caro acid applications in ratios of 3:1 respect to cyanide, thus allowing to obtain cyanide-free tailings.

Mixtures of neutralized gold mine tailings mixed with clay allowed samples with high compression resistance; on the contrary, low compression resistance in samples with volcaninc ashes.

Tailing bricks obtained at plant level comply with Peruvian standard requirements (E-70). In reference to toxicity hazards; there are no risks to human health according to reference values from8 EPA-FCR 261.24.

\section{ACKNOWLEDGEMENTS}

The research was carried out by the Environment and Energy Institute of the Universidad Católica San Pablo in the facilities of the company CEPROMET Minera Porvenir SAC, as part of the project "Development of a prototype for the manufacture of building bricks from gold mine tailings" PIMEN 2012 financed by INNOVATE Peru.

\section{REFERENCES}

[1] M. Van Marrewijk. "Concepts and Definitions of CSR and Corporate Sustainability". J. Bus. Ethics, pp. 2-11. 2002.

[2] V.J. García, A.R. Zúñiga-suárez, C.O. Márquez, J.G. Pérez, F. Fernández-martínez, and F. Hernández-Olivares. "Strength Developing in Clay-Andesite Brick," Mater. Sci. Appl. Vol. 7 No August, pp. 403-420. 2016.

[3] A. Zúñiga-Suárez, F. Hernández-Olivares, F. Fernández-Martínez, B. Zúñiga, L. Sánchez, J. Paladines. "Desarrollo de ladrillos mejorados (LM) y uso de nuevas 
tecnologías en la fabricación de ladrillos ecológicos (LE)". Libr. Actas del $3^{\text {er }}$ Congr. Int. Construcción Sosten. y Soluciones EcoEficientes, Lm, pp. 1206-1218, 2017.

[4] Y. Chen, Y. Zhang, T. Chen, Y. Zhao, and S. Bao. "Preparation of eco-friendly construction bricks from hematite tailings". Constr. Build. Mater. Vol. 25 N $^{\circ}$ 4, pp. 2107 2111. 2011.

[5] S. Roy, G.R. Adhikari, and R.N. Gupta. "Use of gold mill tailings in making bricks: A feasibility study". Waste Manag. Res. Vol. $25 \mathrm{~N}^{\circ}$ 5, pp. 475-482. 2007.

[6] L.F. Dornfeld Braga Colturato, G.B. Ferreira e A. Corrêa de Araújo. "Aproveitamento de rejeitos gerados no beneficiamento de minério de ferro". III Enecs - Encontro Nac. Sobre Edif. E Comunidades Sustentáveis Aproveitamento. 2000.

[7] A. Romero and S. Flores. "Reuso de relaves mineros como insumo para la elaboración de agregados de construcción para fabricar ladrillos y baldosas". Rev. la Fac. Ing. Ind. Univ. Nac. Mayor San Marcos, Perú. Vol. 13 $\mathrm{N}^{\circ}$ 1, pp. 75-82. 2010.

[8] V.M. John and S.E. Zordan. "Research and development methodology for recycling residues as building materials - A proposal". Waste Manag. Vol. 21 № 3, pp. 213-219. 2001.

[9] T. Assawincharoenkij, C. Hauzenberger, and C. Sutthirat. "Mineralogy and geochemistry of tailings from a gold mine in northeastern Thailand". Hum. Ecol. Risk Assess. Vol. 23 $\mathrm{N}^{\circ}$ 2, pp. 364-387. 2017.

[10] M. Malatse and S. Ndlovu. "The viability of using the Witwatersrand gold mine tailings for brickmaking". J. South. African Inst. Min. Metall. Vol. $115 \mathrm{~N}^{\circ}$ 4, pp. 321-327. 2015.

[11] B.J. Mathew, M. Sudhakar, and C. Natarajan. "Strength, Economic and Sustainability Characteristics of Coal Ash - GGBS Based Geopolymer Concrete". Int. J. Comput. Eng. Res. Vol. 3, pp. 207-212. 2013.

[12] G. Agencia de Cooperación Alemana. "Buenas prácticas de gestión ambiental para plantas hidrometalúrgicas de la pequeña minería y minería artesanal que utilizan cianuro", p. 35. 2014.
[13] P. Blanc, M. Hogan, K. Mallin, D. Hryhorczuk, S. Hessl, and B. Bernard. "Cyanide Intoxication Among Silver-Reclaiming Workers". JAMA J. Am. Med. Assoc. Vol. 253 $\mathrm{N}^{\circ}$ 3, pp. 367-371. 1985.

[14] B.M. Ramalinga Reddy, K.S. Satyanarayanan, and H.N. Jagannatha Reddy. "Engineering Properties of Masonry Mortars with Gold Mine Tailings as Partial Substitute for Manufactured Sand". Int. J. Earth Sci. Eng. Vol. $8112 \mathrm{~N}^{\circ}$ 5. 2015.

[15] Y. Yang, S. Zhu, Q. Li, B. Yang, and Y. Chen. "Research on making fired bricks with gold tailings". Proc. - Int. Conf. Comput. Distrib. Control Intell. Environ. Monit. CDCIEM 2011, pp. 1687-1690. 2011.

[16] A. Ferreira de Carvalho, A.M. Coutinho, L.F. Lemos Maia Junior, e V.L. Bretas. engenheiro de minas e supervisor da área do Sistema de Captação e Disposição de Rejeitos da Alcoa Juruti. "Tijolo de rejeito é cinco vezes mais resistente". Minéiros Miner., pp. 24-25. 2017.

[17] E.M.M. Salas. "Proyecto de una Planta Industrial de Ladrillos ecológicos del tipo Suelo-Cemento en Arequipa". Universidad Nacional de Ingenieria. 2015.

[18] A.P.S. Milani e W.J. Freire. "Características Físicas e Mecanicas de Misturas de Solo, Cimento y Casca de Arroz". Eng. Agríc. Vol. $26 \mathrm{~N}^{\mathrm{o}}$ 1, Jan./Apr. 2006.

[19] H.V. Ramos Avilez. "Remoción de cianuro en relaves auríferos utilizando biochar producido a partir de tallos de Gliricidia sepium". Trabajo de grado para optar el título de ingeniero químico. Universidad de Cartagena. Colombia. 2012.

[20] A.G.R. Unda. "Lixiviação em pilhas de minérios de ouro de baixo teor incorporada ao processo de tanques agitados 'Carbon in leaching', uma alternativa econômica no norte do Uruguai. Lixiviação em pilhas de minérios de ouro de baixo teor incorporada ao processo de" Universidade Federal de Minas Gerais Program, Brasil. 2016.

[21] M.T.C. Arellano. "Tratamento de efluentes contendo cianeto por oxigênio singlete gerado através da reação de peróxido de hidrogênio e hipoclorito de sódio”. PUC- Rio. 2012. 